\title{
Use of a colloid to optimize centrifugation in the selection of bovine sperm for IVF
}

\section{Uso de um coloide para otimizar a centrifugação na seleção de espermatozoides bovinos para FIV}

\author{
Cibele Garcia Moreira Gonçalves ${ }^{1}$; Fabio Gallas Leivas ${ }^{2 *}$; Daniele Missio ${ }^{1}$; \\ Francielli Weber Santos²; Eduardo Brum Schwengber ${ }^{3}$; Natalia Picoli Folchini"; \\ Cecilia Urquiza Machado Pavin ${ }^{1}$; Daniela dos Santos Brum²
}

\begin{abstract}
This study aimed to evaluate the effect of the force and duration of centrifugation and the impact of cushioned centrifugation on sperm selection by Percoll gradient, on sperm quality and development kinetics of in vitro produced bovine embryos. Two experiments were performed. In Experiment I, a pool of semen was selected by Percoll gradients and the pellet was divided into four groups and distributed in a $2 \times 2$ factorial, with two forces $(2200 \times \mathrm{g}$ or $9000 \times \mathrm{g})$ and two durations $(1 \mathrm{~min}$ or $3 \mathrm{~min})$ of centrifugation. In Experiment II, semen was divided into two groups and selected by Percoll gradient with Cushion Fluid (CF) or without CF (Control) in the second centrifugation. The morphofunctionality, biochemical characteristics and fertilizing capacity of the selected sperms were evaluated. In addition, the development of the resulting bovine embryos was monitored for $48 \mathrm{~h}$ post-insemination. Duncan and Chi-square tests $(\mathrm{P}<0.05)$ were used to compare the means. In Experiment I, there was a significant increase in sperm vigor $(\mathrm{P}<0.05)$ after sperm selection in all treatments. The force and duration of centrifugation did not have any effect on sperm motility, vigor, and recovery rate among the different treatments $(\mathrm{P}>0.05)$. In Experiment II, the recovery rate and reactive oxygen species (ROS) production in semen were similar among treatments $(\mathrm{P}>0.05)$ although a higher ROS production was observed in the CF fertilization medium. Total fertilization rate was superior in the CF group $(65.4 \pm 5.3 \%)$ compared to that in Control $(39.6 \pm 4.9 \%)$. However, the normal fertilization and cleavage rate did not differ between the Control $(94 \pm 6.3 \%$ and $58.3 \pm 8.3 \%)$ and CF $(89 \pm 7.1 \%$ and $75.0 \pm 7.3 \%)$ groups. The reduction in the force and duration of centrifugation did not decrease the sperm recovery during selection by the Percoll gradient and the use of CF in the second centrifugation did not affect the normal fertilization and development of bovine IVF embryos up to $48 \mathrm{~h}$.
\end{abstract}

Key words: Bovine embryo. Cushion centrifugation. In vitro production. Percoll gradients. Sperm recovery.

\footnotetext{
1 Discentes, Curso de Mestrado, Programa de Pós Graduação em Ciência Animal, Universidade Federal do Pampa, UNIPAMPA, Uruguaiana, RS, Brasil. E-mail: cibelegmg@gmail.com; daniele.missio@yahoo.com.br; cecilia_machado@msn.com

2 Profs. Associado, UNIPAMPA, Uruguaiana, RS, Brasil. E-mail: fabioleivas@unipampa.edu.br; francielliweber@yahoo.com.br; danisbrum@yahoo.com.br

3 Prof. Adjunto, UNIPAMPA, Dom Pedrito, RS, Brasil. E-mail: dududom@hotmail.com

4 Discente, Curso de Graduação em Medicina Veterinária, UNIPAMPA, Uruguaiana, RS, Brasil. E-mail: nataliafolchini@hotmail. com

* Author for correspondence
} 


\section{Resumo}

Esse estudo objetivou avaliar o efeito da força e duração da centrifugação, e o impacto da centrifugação amortecida na seleção espermática por gradientes de Percoll, na qualidade espermática e cinética do desenvolvimento de embriões bovinos produzidos in vitro. Dois experimentos foram realizados. No experimento I, um pool de sêmen foi selecionado por gradientes de Percoll e o pellet dividido em quatro grupos e distribuído em um fatorial 2 x 2, com duas forças (2200 e $9000 \mathrm{X} \mathrm{g}$ ) e dois tempos (1 e 3 min) de centrifugação. No Experimento II, o sêmen foi dividido em dois grupos e selecionado com (CF) ou sem CushionFluid (Controle) na segunda centrifugação. A morfofuncionalidade, características bioquímicas e capacidade fecundante dos espermatozoides selecionados foram avaliadas. Além disso, o desenvolvimento dos embriões bovinos resultantes foi monitorado por 48 horas pós-inseminação. Os testes Duncan e Qui-quadrado $(\mathrm{P}<0,05)$ foram usados para comparar as médias. No Experimento I, houve um aumento significativo no vigor após a seleção espermática para todos os tratamentos. A força e a duração da centrifugação não tiveram nenhum efeito na motilidade, vigor e recuperação espermática entre os diferentes tratamentos $(\mathrm{P}>0.05)$. No Experimento II, a taxa de recuperação e a produção de espécies reativas de oxigênio (EROs) no sêmen foram similares entre os tratamentos ( $\mathrm{P}>0,05)$, embora a maior produção de EROs foi observada no meio de fecundação do grupo CF. A taxa de fecundação total,

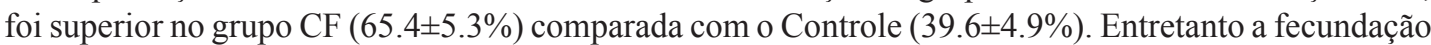
normal e a taxa de clivagem não diferiram entre os grupos Controle $(94 \pm 6.3 \%$ e $58.3 \pm 8.3 \%)$ e CF $(89 \pm 7.1 \%$ and $75.0 \pm 7.3 \%)$. A redução na força e duração da centrifugação não diminuiu a recuperação espermática durante a seleção por gradientes de Percoll e o uso de CF na segunda centrifugação não influenciou a fecundação normal e o desenvolvimento de embriões bovinos PIV até 48 horas.

Palavras-chave: Centrifugação amortecida. Embrião bovino. Gradientes de Percoll. Produção in vitro. Recuperação espermática.

\section{Introduction}

Semen centrifugation is used to concentrate the spermatozoa of different species prior to freezing or in sperm selection protocols for in vitro fertilization (IVF). Although widely used, centrifugation has been considered harmful to the sperm cell, which may cause structural damage and result in decrease of motility and IVF rate (SIEME et al., 2003; MATÁS et al., 2007). The Percoll gradient is the most commonly used method in sperm selection for in vitro production (IVP) of bovine embryos because this technique has a higher sperm recovery rate and has a shorter time of execution when compared to other techniques. However, in the Percoll gradient method, the semen is subjected to two centrifugations that may reduce sperm viability. Other methods of sperm selection, such as the swimup method reduce the use of centrifugation, but this technique is still necessary to concentrate the sample. Studies report that high centrifugal forces often promote higher sperm recovery (WAITE et al., 2008; LEN et al., 2010; GLORIA et al., 2016)
Some studies suggested that a reduction in the force and duration of centrifugation could reduce sperm damage and improve the sperm selection protocol using Percoll gradient (GUIMARÃES et al., 2014; KIM et al., 2013). However, these studies evaluated only the first centrifugation for sperm selection disregarding the second centrifugation for sperm concentration.

Considering that centrifugation can cause irreversible damages to spermatozoa, a cushioning method was developed during the centrifugation of equine semen. In this method, a colloid such as Cushion Fluid (CF) is added to the semen during centrifugation, and a high centrifugal force causes a strong adhesion of the sperm in the pellet (MACPHERSON et al., 2001). Although some studies have shown positive results with this method for stallion (BLISS et al., 2012) and swine semen (MATÁS et al., 2007), there are no studies evaluating the effect of cushioning for bovine semen used for IVF. Therefore, the aim of this study was to evaluate the effects of the reduction in the 
force and duration of centrifugation on the recovery rate and viability of bovine sperm selected by the Percoll gradient, and to assess the use of CF during the second centrifugation for sperm concentration on the fertilization rate and development of bovine IVF embryos.

\section{Materials and Methods}

\section{Chemicals}

Unless stated otherwise, all chemicals were purchased from Sigma Chemical Co. (St. Louis, MO, USA).

\section{Experimental design}

In this research, two experiments were performed. In both experiments, frozen semen from two Bos taurus bulls with proven fertility was used. The straws were thawed at $35^{\circ} \mathrm{C}$ for $20 \mathrm{~s}$ and, semen samples were pooled and then divided into equal fractions. Prior to sperm selection (Pre-Percoll: PP), all sperm samples were evaluated for motility, vigor, concentration (Experiment I and II), and the sperm morphology, integrity and, functionality of the plasma membrane were examined (Experiment II). In Experiment I (5 replicates), after the first centrifugation of the Percoll gradient (90\%, $60 \%$ and $30 \%$ ), the pellet was divided into four fractions and distributed in a $2 \times 2$ factorial design experiment using two forces $(9000 \times \mathrm{g}$ or $2200 \times$ $\mathrm{g})$ and two centrifugation durations (1 $\mathrm{min}$ or 3 $\mathrm{min}$ ) according to the following groups: T1/9000 $\left(9000 \times \mathrm{g} / 1^{\prime}\right) ; \mathrm{T} 3 / 9000\left(9000 \times \mathrm{g} / 3^{\prime}\right) ; \mathrm{T} 1 / 2200$ $\left(2200 \times \mathrm{g} / 1^{\prime}\right)$ and $\mathrm{T} 3 / 2200\left(2200 \times \mathrm{g} / 3^{\prime}\right)$. After centrifugation, the motility, vigor and, sperm recovery rate of the semen samples were evaluated to determine the effects of the force and duration of centrifugation. In Experiment II (5 replicates), after the first centrifugation on the discontinuous Percoll gradient $(90 \%, 60 \%$, and $30 \%)$, the pellet was divided into two fractions and subjected to a second centrifugation performed without $\mathrm{CF}$ (Control) or with CF. After centrifugation, the semen samples were evaluated to determine the effects of $\mathrm{CF}$ on motility, vigor, sperm recovery rate, morphology, integrity, and functionality of plasma membrane, oxidative stress, fertilization rate, and kinetics of embryonic development up to 48 hours postinsemination (hpi).

\section{Sperm quality assessment}

Assessment of motility, vigor, concentration, and sperm morphology

The percentage of motile sperm and vigor were determined subjectively before and after each treatment. An aliquot $(5 \mu \mathrm{L})$ of semen was placed on a pre-warmed glass-slide, overlaid with a cover slip and examined under a bright-field microscope at $100 \times$ magnification. These evaluations were performed by the same person. Sperm concentration was determined with a hemocytometer at a 1:20 dilution. The results are presented as sperm cells $\mathrm{mL}^{-1}$ and, the recovery rate was calculated according to the formula: recovered sperm $(\%)=[($ Final concentration $\times$ final Volume) / (Initial concentration $\times$ initial volume $)] \times 100($ MACHADO et al., 2009) .

In order to assess the sperm morphology, an aliquot $(10 \mu \mathrm{L})$ of fixed sperm suspension was placed on a microscope slide, overlaid with a cover slip and permitted to settle in a humidified chamber for $2 \mathrm{~min}$. A total of 200 sperm cells were assessed and, the percentage of spermatozoa with abnormal morphology was determined using phase-contrast microscopy $(1000 \times$ magnification $)$ based on a method described by Barth and Oko (1989).

\section{Assessment of the integrity and functionality of the sperm plasma membrane}

Sperm membrane integrity was assessed using 6-carboxy fluorescein diacetate (CFDA) and propidium iodide (PI) as described by Harrison and 
Vickers (1990). An aliquot (5 $\mu \mathrm{L})$ of the stained suspension was placed on a slide, covered with a coverslip and observed under an epifluorescence microscope (400 X magnification). On each slide, 200 sperm cells were counted and classified as having an intact or damaged plasma membrane. Cells stained green with CFDA have an intact membrane, whereas those stained red with PI were deemed to have a damaged membrane. Sperm membrane functionality was determined using the hypo-osmotic swelling test (HOS), as described by Lomeo and Giambersio (1991). The assay was performed by mixing $10 \mu \mathrm{L}$ of semen with $50 \mu \mathrm{L}$ of hypo-osmotic solution (100 mOsm) and incubating at $37^{\circ} \mathrm{C}$ for $45 \mathrm{~min}$. A total of 100 cells were evaluated in at least five different fields under $400 \mathrm{X}$ magnification. Spermatozoa with swollen or coiled tails were denoted as HOS positive (HOS+).

\section{Assessment of oxidative stress}

Oxidative stress was evaluated by quantifying the levels of ROS and glutathione (GSH), and the activity of superoxide dismutase (SOD). ROS levels were measured by a spectrofluorimetric method (LOETCHUTINAT et al., 2005), where the sperm was incubated in Tris- $\mathrm{HCl}$ in the presence of 2',7'-dichloro dihydrofluorescein diacetate (DCHFDA) for $60 \mathrm{~min}$ at $37^{\circ} \mathrm{C}$ in the dark. This dye is a fluorogenic probe commonly used to detect cellular ROS production. DCHFDA is a stable, cellpermeable non fluorescent probe. It is de-esterified intracellularly and becomes the highly fluorescent 2',7'-dichlorofluorescein (DCF) upon oxidation. The oxidation of DCHFDA to fluorescent DCF was used to detect and measure the intracellular ROS. The DCF fluorescence emission intensity was recorded at $520 \mathrm{~nm}$ (with $480 \mathrm{~nm}$ excitation) using a Shimadzu spectrofluorometer. ROS levels were expressed in the arbitrary units of fluorescence (UF).

The GSH levels were determined using a spectrofluorimetric method as described by Hissin and Hilf (1976) using O-phthalaldehyde (OPA) as a fluorophore. The spermatozoa $(10 \mu \mathrm{L})$ were incubated with $10 \mu \mathrm{L}$ of OPA $(0.1 \%$ in methanol) and $180 \mu \mathrm{L}$ of $0.1 \mathrm{M}$ phosphate buffer $(\mathrm{pH} 8.0)$ for $15 \mathrm{~min}$ at room temperature in the dark. The fluorescence was measured with a Hidex Plate Chameleon V Multi-technology Platereader, model 425-156, at an excitation wave length of $350 \mathrm{~nm}$ and an emission wave length of $420 \mathrm{~nm}$. The GSH levels were expressed as nmol $\mathrm{mL}^{-1}$. The activity of SOD was determined as described by Misra and Fridovich (1972). This method is based on the ability of SOD to inhibit the auto-oxidation of adrenaline to adrenochrome. The absorbance of the color reaction was measured at $480 \mathrm{~nm}$. One unit of enzyme (1 IU) is defined as the amount of enzyme required to inhibit the rate of auto-oxidation of adrenaline to $50 \%$ at $26^{\circ} \mathrm{C}$.

\section{In vitro embryo production (IVP)}

Ovaries were collected immediately after slaughter and transported to the laboratory in a saline solution $(0.9 \% \mathrm{NaCl})$ supplemented with antibiotics (100 IU mL $\mathrm{mL}^{-1}$ penicillin and $100 \mu \mathrm{g}$ $\mathrm{mL}^{-1}$ streptomycin) maintained at $30^{\circ} \mathrm{C}$. Cumulusoocyte complexes (COCs) were aspirated from 2 - $8 \mathrm{~mm}$ diameter follicles using a 18 gauge needle attached to a vacuum pump. Only those COCs with a homogenous cytoplasm and at least three layers of cumulus cells were used. Groups of 22 COCs were allowed to mature in vitro within $150 \mu \mathrm{L}$-drops of modified TCM-199 medium with 10\% estrus mare serum. This medium was supplemented with $5 \mu \mathrm{g}$ $\mathrm{mL}^{-1}$ of porcine follicle-stimulating hormone, NIHFSH-P1 (Folltropin-V ${ }^{\circledR}$, Bioniche Animal Health, Ontario, Canadá), $50 \mu \mathrm{g} \mathrm{mL}^{-1}$ of porcine pituitary luteinizing hormone, LH-P (Lutropin- $\mathrm{V}^{\circledR}$, Bioniche Animal Health), $100 \mu \mathrm{g} \mathrm{mL} \mathrm{m}^{-1}$ of human epidermal growth factor (hEGF) and $22 \mu \mathrm{g} \mathrm{mL} \mathrm{m}^{-1}$ of pyruvate and gentamicin. The COCs were cultured for $24 \mathrm{~h}$ at $39^{\circ} \mathrm{C}$ in a gaseous atmosphere with $5 \% \mathrm{CO}_{2}$ in air and saturated humidity for in vitro maturation. 
An isotonic Percoll solution was used in the preparation of $90 \%, 60 \%$ and $30 \%$ Percoll solutions with modified Talp-Fert medium for sperm selection (PARRISH et al., 1986). A discontinuous Percoll gradient was created by layering $300 \mu \mathrm{L}$ of each solution into a microtube, starting with the $90 \%$ Percoll solution at the bottom of the tube followed by the $60 \%$ and $30 \%$ solutions. On the top of the gradient, $200 \mu \mathrm{L}$ of thawed semen was layered, and the tubes were centrifuged for $5 \mathrm{~min}$ at 2200 x g (GUIMARÃES et al., 2014). In Experiment I, the pellets were suspended in $300 \mu \mathrm{L}$ of Talp-Fert medium and centrifuged at $9000 \times \mathrm{g}$ or $2200 \mathrm{x} \mathrm{g}$ for $1 \mathrm{~min}$ or $3 \mathrm{~min}$, depending on the treatment. In Experiment II, the second centrifugation was performed at $2200 \times \mathrm{g}$ for $1 \mathrm{~min}$ with or without the addition of $150 \mu \mathrm{L}$ of CF. Droplets containing $150 \mu \mathrm{L}$ a modified Talp-Fert medium (PARRISH et al., 1995), $22 \mu \mathrm{g} \mathrm{mL} \mathrm{mL}^{-1}$ pyruvate, $6 \mathrm{mg} \mathrm{mL}^{-1} \mathrm{BSA}$, $10 \mu \mathrm{g} \mathrm{mL}^{-1}$ heparin, $20 \mu \mathrm{M} \mathrm{mL}^{-1}$ penicillamine, 10 $\mu \mathrm{M}$ hypotaurine and $2 \mu \mathrm{M} \mathrm{mL}^{-1}$ epinephrine were prepared in dishes under mineral oil for in vitro CCOs fertilization (Day 0) with $2 \times 10^{6}$ sperm cells $\mathrm{mL}^{-1}$. The sperm and oocyte co-culture was carried out at $39{ }^{\circ} \mathrm{C}$ in a gaseous atmosphere with $5 \% \mathrm{CO}_{2}$ in air and saturated humidity. For the evaluation of fertilization, the potential zygotes at 18 hpi were stained for 15 min (1\% Hoechst 33342 in PBS), washed with PBS containing $1 \mathrm{mg} \mathrm{mL}^{-1}$ polyvinylpyrrolidone, mounted on glass slides, and examined under an epifluorescence microscope (400 $\times$ magnification). The fertilization was evaluated by pronucleus formation. Oocytes that had one or more spermatozoa with a decondensed head and the presence of two or more pronuclei, fused pronuclei or cleaved embryos were considered as markers for total fertilization. Zygotes that had two pronuclei or a fused nucleus were considered as normally fertilized oocytes

The cumulus oophorus cells were removed by successive pipetting for in vitro culture (IVC). The IVC medium used was Synthetic Oviduct Fluid with amino acids, citrate, and myoinositol (HOLM et al., 1999). The embryos were individually transferred to the microwells of a well-of-the-well (WOW) culture dish (Primo Vision dish, CryoInnovation Technologies, Budapest, Hungary) and cultured in groups under mineral oil at $39{ }^{\circ} \mathrm{C}$ in a gaseous atmosphere with $5 \% \mathrm{CO}_{2}$ in air and saturated humidity till 48 hpi. The WOW culture dishes were placed on the stages of compact digital inverted microscopes designed to be used inside an incubator, and capable of automated timelapse analysis (Primo Vision time-lapse embryo monitoring system, Cryo-Innovation Technologies, Budapest, Hungary). Imaging frequency was set to $5 \mathrm{~min}$. The embryos were individually evaluated 48 hpi for cleavage, moment of the first cleavage and the number of cells.

\section{Statistical analysis}

The effects of the duration and force of centrifugation, and the use of $\mathrm{CF}$ in the second centrifugation on sperm motility, vigor, morphology, integrity and, functionality of the plasma membrane were analyzed using a one-way analysis of variance (ANOVA) followed by the Duncan's multiple range test when appropriate. Recovery rate, oxidative stress, fertilization rate and embryonic developmental kinetics were analyzed by the chisquare test. Values of $\mathrm{P}<0.05$ were considered to be statistically significant.

\section{Results}

In Experiment I, the duration and force of the second centrifugation in the Percoll gradient method did not affect the sperm motility $(\mathrm{P}=0.281)$ among treatments (T1/9000, T3/9000, T1/2200, and T3/2200) and PP sample values. However, the sperm vigor was similar $(\mathrm{P}>0.05)$ among treatments (T1/9000, T3/9000, T1/2200 and T3/2200) and superior to $\mathrm{PP}$ sample values $(\mathrm{P}<0.05)$. The sperm recovery rate was similar among treatments $(\mathrm{P}=$ 0.348; Table 1). 
Table 1. Bovine sperm characteristics evaluated prior sperm selection (PP) and after the second centrifugation with different forces and durations of centrifugation.

\begin{tabular}{|c|c|c|c|c|c|}
\hline Sperm characteristics & $\mathbf{P P}$ & $\begin{array}{c}\text { T1/9000 } \\
\left(9000 \times \mathrm{g} / \mathbf{1}^{\prime}\right)\end{array}$ & $\begin{array}{c}\text { T3/9000 } \\
(9000 \times \text { g/3') }\end{array}$ & $\begin{array}{c}\mathrm{T} 1 / 2200 \\
\left(2200 \times \mathrm{g} / \mathbf{1}^{\prime}\right)\end{array}$ & $\begin{array}{c}\mathrm{T} 3 / 2200 \\
\left(2200 \times \mathrm{g} / \mathbf{3}^{\prime}\right)\end{array}$ \\
\hline Motility & 70.0 & $76.0 \pm 5.3$ & $76.1 \pm 5.5$ & $74.0 \pm 5.5$ & $70.0 \pm 7.1$ \\
\hline Vigor & $3.0^{\mathrm{a}}$ & $4.2 \pm 0.4^{b}$ & $3.6 \pm 0.6^{\mathrm{b}}$ & $3.8 \pm 0.4^{b}$ & $3.4 \pm 0.6^{\mathrm{b}}$ \\
\hline Recovery Rate & - & $40.6 \pm 8.9$ & $34.4 \pm 7.2$ & $42.4 \pm 11.4$ & $36.0 \pm 5.7$ \\
\hline
\end{tabular}

Data are expressed as mean $\pm \mathrm{SD}$. ${ }^{\mathrm{a}, \mathrm{b}}$ Within a row, the values without a common letter differed $(\mathrm{P}<0.05)$.

In Experiment II, the use of CF in the second centrifugation of the discontinuous Percoll gradients did not affect $(\mathrm{P}>0.05)$ motility, vigor, and plasma membrane integrity among treatments, and neither treatment values were comparable to PP sample values (Table 2). There was a significant decrease (P $<0.05)$ in the plasma membrane functionality in the Control and CF samples compared to the PP samples. Spermatozoa morphology was not influenced ( $\mathrm{P}$ $>0.05$ ) using $\mathrm{CF}$ in the second centrifugation, but a significant decrease in the frequency of sperm defects was observed in the Control and CF samples when compared to PP samples $(\mathrm{P}<0.05)$. The sperm recovery rate was similar between the Control and $\mathrm{CF}$ groups $(\mathrm{P}>0.05)$. ROS levels in semen were not influenced by any treatment $(\mathrm{P}>0.05)$. However, there was a significant increase $(\mathrm{P}<0.05)$ in ROS levels in the fertilization medium when $\mathrm{CF}$ was used (Table 2). The levels of SOD and GSH in semen were similar between Control $(35 \pm 6.1 \mathrm{IU}$ and $470 \pm 152.7 \mathrm{mM}$, respectively) and CF groups $(30.5 \pm 6.2 \mathrm{IU}$ and $384 \pm 117.8 \mathrm{mM}$, respectively). Total fertilization rate was superior in the CF group compared to the Control group (Table 3). However, when normal fertilization was evaluated, there was no difference between the Control and CF groups (P $>0.05)$. No differences in the cleavage rate, time of first cleavage and cell number was observed among treatments till 48 hpi $(\mathrm{P}>0.05)$.

Table 2. Bovine sperm characteristics evaluated prior sperm selection (PP) and after the second centrifugation with (CF) or without (Control) Cushion Fluid.

\begin{tabular}{lccc}
\hline Sperm characteristics & PP & Control & CF \\
\hline Motility (\%) & $80.0 \pm 10.0$ & $78.0 \pm 4.5$ & $68.0 \pm 8.4$ \\
Vigor (1-5) & $3.8 \pm 0.4$ & $4.2 \pm 0.8$ & $4.0 \pm 0.7$ \\
Recovery Rate (\%) & - & $42.0 \pm 4.9$ & $38.6 \pm 3.6$ \\
\hline Functional Plasma Membrane (\%) & $51.8 \pm 2.2^{\mathrm{a}}$ & $38.1 \pm 8.7^{\mathrm{b}}$ & $35.3 \pm 3.2^{\mathrm{b}}$ \\
Intact Plasma Membrane (\%) & $57.0 \pm 15.4$ & $40.6 \pm 21.1$ & $61.6 \pm 14.4$ \\
Total Defects (\%) & $21.8 \pm 2.5^{\mathrm{a}}$ & $12.6 \pm 2.1^{\mathrm{b}}$ & $10.4 \pm 2.6^{\mathrm{b}}$ \\
ROS (UF) & & & \\
Semen & - & $21.9 \pm 8.5$ & $27.4 \pm 8.7$ \\
Medium & - & $30.9 \pm 9.3^{\mathrm{b}}$ & $79.9 \pm 21.5^{\mathrm{a}}$ \\
\hline
\end{tabular}

Data are expressed as mean $\pm \mathrm{SD}$. ${ }^{\mathrm{a}, \mathrm{b}}$ Within a row, the values without a common letter differed $(\mathrm{P}<0.05)$. 
Table 3. Fertilization rate and embryonic developmental kinetics during in vitro fertilization using bovine sperm selected by Percoll with (CF) or without (Control) addition of CushionFluid during the second centrifugation.

\begin{tabular}{ccccccc}
\hline Treatments & N & $\begin{array}{c}\text { Total Fertilization } \\
\text { Rate (\%) }\end{array}$ & N & $\begin{array}{c}\text { Cleavage } \\
\mathbf{( \% )}\end{array}$ & $\begin{array}{c}\text { First } \\
\text { Cleavage(h) }\end{array}$ & $\begin{array}{c}\text { Cell Number } \\
\text { (n)** }\end{array}$ \\
\hline Control & 101 & $39.6 \pm 4.9^{\mathrm{b}}$ & 36 & $58.3 \pm 8.3$ & $33.9 \pm 1.31$ & $3.1 \pm 0.36$ \\
$\mathbf{C F}$ & 81 & $65.4 \pm 5.3^{\mathrm{a}}$ & 36 & $75.0 \pm 7.3$ & $33.7 \pm 1.19$ & $3.2 \pm 0.29$ \\
\hline
\end{tabular}

Data are expressed as mean \pm SD. * Cell number at 48 hpi $(\mathrm{P}<0.05)$.

\section{Discussion}

Semen centrifugation is done with the spermatozoa of different species to eliminate fractions of seminal plasma and/or to concentrate sperm before artificial insemination or cryopreservation (RIJSSELAERE et al., 2002). It is additionally used for sperm selection for in vitro production IVP. Regardless of sperm selection method used, centrifugation is required to concentrate the sperm sample in IVP. Although several studies examine the effects of the sperm selection method on sperm characteristics or report possible damage caused by centrifugation (DELL'AQUA JÚNIOR et al., 2006; MACHADO et al., 2009; GUIMARÃES et al., 2014), there are no studies evaluating the effect of the second centrifugation performed during selection by Percoll gradients. In this study, we were able to prove that a lower duration $(1 \mathrm{~min})$ and force $(2200 \mathrm{x} \mathrm{g})$ in the second centrifugation of Percoll gradient did not reduce the sperm recovery rate.

The use of a colloid to protect sperm cells from gravitational forces during the first centrifugation has been reported to be successful in some studies (MATÁS et al., 2007; BLISS et al., 2012). Research has reported the use of iodixanol as a density gradient medium and cryoprotectant for bovine semen (SARAGUSTY et al., 2009). In the present study, the use of CF during the second centrifugation of the Percoll gradient did not improve sperm characteristics after selection, differing from the results reported for equine and swine semen (BLISS et al., 2012; MARTINEZ-ALBORCIA et al., 2013). This could have been due to several factors such as the reduced volume of semen and the centrifugation time used in the present study. Unlike the protocols for swine and stallions, it uses the cushioned centrifugation for large volumes of ejaculate and a longer duration of centrifugation (BLISS et al., 2012; LEN et al., 2010; MATÁS et al., 2007). Therefore, this study reports for the first time, the use of CF for the selection of cryopreserved bovine semen. In addition, it is known that the reduction in sperm viability after selection cannot always be detected by evaluations performed immediately after semen processing, showing that such alterations may decrease fertilization rates and/or embryonic development (SHARMA; AGARWAL, 1996; KATKOV; MAZUR, 1998). The evaluation of oxidative stress has been suggested to be an important marker for sperm viability in humans (AGARWAL et al., 2014), swine (RADOMIL et al., 2011), stallions (BAUMBER et al., 2000) and bulls (SIMÕES et al., 2013). This is due to the fact that it can help predict damage before the actual morphological and functional damage occurs in the sperm. In the present study, we evaluated the production of ROS and the activity of two antioxidants (SOD and GSH) in the semen after sperm selection and in the fertilization medium after co-culture of oocytes and spermatozoa. In recent years, ROS production in the male reproductive system has been recognized as a real concern due to its deleterious effects when present at high levels in the semen (SALEH; AGARWAL, 2002; BANSAL; PARLE, 2011; TVRDÁ et al., 2011). Matás et al. (2007) did not observe differences in ROS production when using the cushioned centrifugation 
for boar semen. However, we observed that there was a higher production of ROS in the fertilization medium when $\mathrm{CF}$ was used, although there was no difference among treatments with respect to ROS production in the sperm. This result could have been probably due to the possible removal of the cushion medium along with the removal of the semen pellet to be used in the IVF. Since, this technique demands great operator ability due to the small size of the columns and the difficulty in clearly seeing, such a scenario is plausible.

The semen used in IVF can directly influence fertilization rate and embryonic development (WARD et al., 2001; SIEME et al., 2003; MATÁS et al., 2007). In the present study, a higher fertilization rate was observed when $\mathrm{CF}$ was used during the sperm selection. As sperm capacitation may be a part of the oxidative process (AITKEN, 1999; O'FLAHERTY et al., 1999; ALI et al., 2003; FUNAHASHI; SANO, 2005), the increase in fertilization rates in the present study can be due to a higher amount of ROS detected in the fertilization medium in the CF group. However, as the antioxidant level of gametes during fertilization seems to be paradoxical, being positive for the surviving of oocytes, but negative or positive for fertilization depending on the balance between the amount of ROS produced and eliminated (BLONDIN et al., 1997; ALI et al., 2003; GONÇALVES et al., 2010), this difference was not sustained when considering only the normal fertilization or the embryonic development.

Monitoring the embryonic developmental kinetics is an important means for the evaluation of the in vitro culture system, oocyte competence, and sperm capacity. Different studies (LONERGAN et al., 1999; BARRETA et al., 2012) reported that the moment of the first embryonic cleavage is directly related to its capacity for future development, suggesting that embryos that divide more prematurely (up to $30 \mathrm{hpi}$ ) have better chances to develop to the stage of blastocyst and result in pregnancy. In this study, it was not possible to verify the harmful effects of the CF on the moment of the first cleavage and on the average number of cells at $48 \mathrm{hpi}$, indicating the absence of iodixanol toxicity.

\section{Conclusion}

The reduction in the centrifugal force to $2200 \mathrm{x}$ $\mathrm{g}$ and the centrifugation duration to $1 \mathrm{~min}$ during the second centrifugation of the Percoll gradient method did not reduce sperm motility, vigor and, recovery. The use of Cushion Fluid during the second centrifugation did not decrease the sperm recovery rate, ROS levels, antioxidant defenses, normal fertilization, and the development of bovine embryos up to 48 hpi.

\section{Acknowledgments}

The authors thank Minitube of Brazil for providing the Cushion Fluid.

\section{References}

AGARWAL, A.; VIRK, G.; ONG, C.; DU PLESSIS, S. $\mathrm{S}$. Effect of oxidative stress on male reproduction. The World Journal of Men's Health, Seoul, v. 32, n. 1, p. 1-17, 2014.

AITKEN, R. J. The amoroso lecture. The human spermatozoon-a cell in crisis? Journal of Reproduction and Fertility, Cambridge, v. 115, n. 1, p. 1-7, 1999.

ALI, A. A.; BILODEAU, J. F.; SIRARD, M. A. Antioxidant requirements for bovine oocytes vary during in vitro maturation, fertilization and development. Theriogenology, California, v. 59, n. 3-4, p. 939-949, 2003.

BANSAL, N.; PARLE, M. Beneficial effect of chyawanprash on cognitive function in aged mice. Pharmaceutical Biology, London, v. 49, n. 1, p. 2-8, 2011.

BARRETA, M. H.; GASPERIN, B. G.; RISSI, V. B.; CESARO, M. P.; OLIVEIRA, J. F.; GONÇALVES, P. B. D.; BORDIGNON, V. Homologous recombination and non-homologous end-joining repair pathways in bovine embryos with different developmental competence. Experimental Cell Research, New York, v. 318, n. 16, p. 2049-2058, 2012. 
BARTH, A. D.; OKO, R. J. Abnormal morphology of bovine spermatozoa. Ames: Iowa State University Press, 1989. 285 p.

BAUMBER, J.; BALL, B. A.; GRAVANCE, C. G.; MEDINA, V.; DAVIES-MOREL, M. C. G. The effect of reactive oxygen species on equine sperm. Journal of Andrology, Philadelphia, v. 21, n. 6, p. 895-902, 2000.

BLISS, S. B.; VOGE, J. L.; HAYDEN, S. S.; TEAGUE, S. R.; BRINSKO, S. P.; LOVE, C. C.; BLANCHARD, T. L.; VARNER, D. D. The impact of cushioned centrifugation protocols on semen quality of stallions. Theriogenology, California, v. 77, n. 6, p. 1232-1239, 2012.

BLONDIN, P.; COENEN, K.; SIRARD, M. A. The impact of reactive oxygen species on bovine sperm fertilizing ability and oocyte maturation. Journal of Andrology, Philadelphia, v. 18, n. 4, p. 454-460, 1997.

DELL'AQUA JÚNIOR, A.; PAPA, F. O.; ARAÚJO JÚNIOR, J. P.; FREITAS, C. P.; PONCHIROLLI, C. B.; FIGUEIREDO, A. S. Application of sexed sorted semen in embryo production. Acta Scientiae Veterinariae, Porto Alegre, v. 34, n. 1, p. 205-212, 2006.

FUNAHASHI, H.; SANO, T. Select antioxidants improve the function of extended boar semen stored at 10 degrees C. Theriogenology, California, v. 63, n. 6, p. 1605-1616, 2005.

GLORIA, A.; CARLUCCIO, A.; WEGHER, L.; ROBBE, D.; BEFACCHIA, G.; CONTRI, A. Single and double layer centrifugation improve the quality of cryopreserved bovine sperm from poor quality ejaculates. Journal of Animal Science and Biotechnology, London, v. 7, p. 3038, 2016.

GONÇALVES, F. S.; BARRETTO, L. S.; ARRUDA, R. P.; PERRI, S. H.; MINGOTI, G. Z. Effect of antioxidants during bovine in vitro fertilization procedures on spermatozoa and embryo development. Reproduction in Domestic Animals, Berlin, v. 45, n. 1, p. 129-135, 2010.

GUIMARÃES, A. C.; LEIVAS, F. G.; SANTOS, F. W.; SCHWENGBER, E. B.; GIOTTO, A. B.; MACHADO, C. I.; GONÇALVES, C. G.; FOLCHINI, N. P.; BRUM, D. S. Reduction of centrifugation force in discontinuous Percoll ${ }^{\circledR}$ gradients increases in vitro fertilization rates without reducing bovine sperm recovery. Animal Reproduction Science, Amsterdam, v. 146, n. 3-4, p. 103$110,2014$.

HARRISON, R. A.; VICKERS, S. E. Use of fluorescent probes to assess membrane integrity in mammalian spermatozoa. Journal of Reproduction and Fertility, Cambridge, v. 88, n. 1, p. 343-352, 1990.

HISSIN, P. J.; HILF, R. A fluorometric method for determination of oxidized and reduced glutathione in tissues. Analytical biochemistry, Orlando, v. 74, n. 1, p. 214-226, 1976.

HOLM, P.; BOOTH, P. J.; SCHMIDT, M. H.; GREVE, T.; CALLESEN, H. High bovine blastocyst development in a static in vitro production system using SOFaa medium supplemented with sodium citrate and myo-inositol with or without serum-proteins. Theriogenology, California, v. 52, n. 4, p. 683-700, 1999.

KATKOV, I. I.; MAZUR, P. Influence of centrifugation regimes on motility, yield, and cell associations of mouse spermatozoa. Journal of Andrology, Philadelphia, v. 19, n. 2, p. 232-241, 1998.

KIM, S.; AGCA, C.; AGCA, Y. Effects of various physical stress factors on mitochondrial function and reactive oxygen species in rat spermatozoa. Reproduction, Fertility, and Development, East Melbourne, v. 25, n. 7, p. 1051-1064, 2013.

LEN, J.A.; JENKINS, J.A.; EILTS, B.E.; PACCAMONTI, D. L.; LYLE, S. K.; HOSGOOD, G. Immediate and delayed (after cooling) effects of centrifugation on equine sperm. Theriogenology, California, v. 73, n. 2, p. 225-231, 2010.

LOETCHUTINAT, C.; KOTHAN, S.; DECHSUPA, S.; MEESUNGNOEN, J.; JAY-GERIN, J. P.; MANKHETKORN, S. Spectrofluorometric determination of intracellular levels of reactive oxygen species in drug-sensitive and drug-resistant cancer cells using the 2',7'-dichlorofluorescein diacetate assay. Radiation Physics and Chemistry, Nova York, v. 72, n. 2-3, p. 323-331, 2005.

LOMEO, A. M.; GIAMBERSIO, A. M. Water-test: a simple method to assess sperm-membrane integrity. International Journal of Andrology, Copenhagen, v. 14, n. 4, p. 278-282, 1991.

LONERGAN, P.; KHATIR, H.; PIUMI, F.; RIEGER, D.; HUMBLOT, P.; BOLAND, M. P. Effect of time interval from insemination to first cleavage on the developmental characteristics, sex ratio and pregnancy rate after transfer of bovine embryos. Journal of Reproduction and Fertility, Cambridge, v. 117, n. 1, p. 159-167, 1999.

MACHADO, G. M.; CARVALHO, J. O.; SIQUEIRA FILHO, E.; CAIXETA, E. S.; FRANCO, M. M.; RUMPF, R.; DODE, M. A. Effect of Percoll $($ volume, duration and force of centrifugation, on in vitro production and sex ratio of bovine embryos. Theriogenology, California, v. 71, n. 8, p. 1289-1297, 2009.

MACPHERSON, M. L.; SHORE, M. D.; FERNANDEZ, M. H.; MILLER, C. D.; THOMPSON, J. A.; BLANCHARD, T. L.; VARNER, D. D. Processing factors which influence viability and fertility of cryopreserved 
equine spermatozoa. Havemeyer Found, Monograf Series, New Orleans, v. 6, p. 27-29, 2001.

MARTINEZ-ALBORCIA, M. J.; MORRELL, J. M.; GIL, M. A.; BARRANCO, I.; MASIDE, C.; ALKMIN, D. V.; PARRILLA, I.; MARTINEZ, E. A.; ROCA, J. Suitability and effectiveness of single layer centrifugation using Androcoll-P in the cryopreservation protocol for boar spermatozoa. Animal Reproduction Science, Amsterdam, v. 140, n. 3-4, p. 173-179, 2013.

MATÁS, C.; DECUADRO, G.; MARTÍNEZ-MIRÓ, S.; GADEA, J. Evaluation of a cushioned method for centrifugation and processing for freezing boar semen. Theriogenology, California, v. 67, n. 5, p. 1087-1091, 2007.

MISRA, H. P.; FRIDOVICH, I. The role of superoxide anion in the autoxidation of epinephrine and a simple assay for superoxide dismutase. The Journal of Biological Chemistry, Baltimore, v. 247, n. 10, p. 3170-3175, 1972.

O'FLAHERTY, C. M.; BEORLEGUI, N. B.; BECONI, M. T. Reactive oxygen species requirements for bovine sperm capacitation and acrosome reaction. Theriogenology, California, v. 52, n. 2, p. 289-301, 1999.

PARRISH, J. J.; KROGENAES, A.; SUSKO-PARRISH, J. L. Effect of bovine sperm separation by either swimup or Percoll@ method on success of in vitro fertilization and early embryonic development. Theriogenology, California, v. 44, n. 6, p. 859-869, 1995.

PARRISH, J. J.; SUSKO-PARRISH, J. L.; LEIBFRIEDRUTLEDGE, M. L.; CRITSER, E. S.; EYESTONE, W. H.; FIRST, N. L. Bovine in vitro fertilization with frozenthawed semen. Theriogenology, California, v. 25, n. 4, p. 591-600, 1986.

RADOMIL, L.; PETTITT, M. J.; MERKIES, K. M.; HICKEY, K. D.; BUHR, M. M. Stress and dietary factors modify boar sperm for processing. Reproduction in Domestic Animals, Berlin, v. 46, n. 2, p. 39-44, 2011.

RIJSSELAERE, T.; VAN SOOM, A.; MAES, D.; DE KRUIF, A. Effect of centrifugation on in vitro survival of fresh diluted canine spermatozoa. Theriogenology, California, v. 57, n. 6, p. 1669-1681, 2002.
SALEH, R. A.; AGARWAL, A. Oxidative stress and male infertility: from research bench to clinical practice. Journal of Andrology, Philadelphia, v. 23, n. 6, p. 737752, 2002.

SARAGUSTY, J.; GACITUA, H.; ROZENBOIM, I.; ARAV, A. Protective effects of iodixanol during bovine sperm cryopreservation. Theriogenology, Califórnia, v. 71, n. 9, p. 1425-1432, 2009.

SHARMA, R. K.; AGARWAL, A. Role of reactive oxygen species in male infertility. Urology, Ridgewood, v. 48, n. 6, p. 835-850, 1996.

SIEME, H.; MARTINSSON, G.; RAUTERBERG, H.; WALTER, K.; AURICH, C.; PETZOLDT, R.; KLUG, E. Application of techniques for sperm selection in fresh and frozen-thawed stallion semen. Reproduction in Domestic Animals, Berlin, v. 38, n. 2, p. 134-140, 2003.

SIMÕES, R.; FEITOSA, W. B.; SIQUEIRA, A. F. P.; NICHI, M.; PAULA-LOPES, F. F.; MARQUES, M. G.; PERES, M. A.; BARNABE, V. H.; VISINTIN, J. A.; ASSUMPÇAÕ, M. E. O. Influence of bovine sperm DNA fragmentation and oxidative stress on early embryo in vitro development outcome. Reproduction, Cambridge, v. 146, n. 5, p. 433-441, 2013.

TVRDÁ, E.; KŇAŽICKÁ, Z.; BÁRDOS, L.; MASSÁNYI, P.; LUKÁČ, N. Impact of oxidative stress on male fertility - a review. Acta Veterinaria Hungarica, Budapest, v. 59, n. 4, p. 465-484, 2011.

WAITE, J. A.; LOVE, C. C.; BRINSKO, S. P.; TEAGUE, S. R.; SALAZAR, J. L.; MANCILL, S. S.; VARNER, D. D. Factors impacting equine sperm recovery rate and quality following cushioned centrifugation. Theriogenology, California, v. 70, n. 4, p. 704-714, 2008.

WARD, F.; RIZOS, D.; CORRIDAN, D.; QUINN, K.; BOLAND, M.; LONERGAN, P. Paternal influence on the time of first embryonic cleavage post insemination and the implications for subsequent bovine embryo development in vitro and fertility in vivo. Molecular Reproduction and Development, New York, v. 60, n. 1, p. 47-55, 2001. 